\title{
MAKING SENSES of Appetite, Love and Lust in Io Sono L'Amore (2009)
}

\section{Joana Caetano}

Universidade do Porto

\begin{abstract}
Sensation is fundamental to our experience of the world. Shaped by culture, gender, and class, the senses mediate between mind and body, idea and object, self and environment." (The Senses and the Society Journal). After centuries of what one might call "the religion of reason", during which the senses, the body and the life of emotions have been mistreated and repressed, we are witnessing a return of subjectivism and its reactions regarding identity. The quotation above points to a theory in Cultural Studies that has recently emerged in academia: Sensory Studies. According to this approach, the senses are essential to the human experience of reality and the understanding of the world: more than employing their senses and being shaped by them, human beings construct them. At the heart of Sensory Studies is the thesis of the mediatory role of senses in the production of experience. Since, as Laplantine claims, cinema is made up of "permanently transforming sensations," films can be the ideal means to think sensually. Inspired by this view and the theory that bodies are not simple objects of thought nor are they fixed into their own boundaries (cf. J. Butler), this paper will focus on the analysis of the Italian film Io Sono L'Amore (2009) by Luca Guadagnino. Although the film seems to depict a common story, it is, in fact, a deeply stylized narrative of the senses - an aestheticization of everyday life and a utopian construal of the body. Applying conceptual tools from both Sensory Studies and Food Studies, we will travel through Emma Recchi's physical and emotional journey of delight, and try to comprehend how fine food can lead to desire, the pleasures of the flesh and a more profound knowledge of oneself.
\end{abstract}

Keywords: Sensory Studies, Gender Studies, the Body, Utopia, and Cinema 
Resumo: "Sensation is fundamental to our experience of the world. Shaped by culture, gender and class, the senses mediate between mind and body, idea and object, self and environment." (The Senses and the Society Journal). Após séculos do que se poderá chamar a "religião da razão", durante a qual os sentidos, o corpo e as emoções foram mal compreendidos e reprimidos, testemunhamos um regresso do subjetivismo e das suas reações em termos de identidade. A citação acima aponta para uma teoria da área dos Estudos Culturais que emergiu recentemente na academia: os Estudos sobre os Sentidos. De acordo com esta tendência, os sentidos são essenciais para a experiência humana da realidade e para a compreensão do mundo: mais do que empregarem os seus sentidos e serem moldados por eles, os seres humanos constroem-nos. A tese de que os sentidos têm um papel mediador na produção da experiência é a base desta nova área de estudo. Uma vez que, como afirma Laplantine, o cinema é constituído por "sensações permanentemente transformadoras", os filmes podem ser o meio ideal para pensar sensorialmente. Inspirado por este ponto de vista e pela teoria de que os corpos não são simples objetos de pensamento nem estão fixos nos seus próprios limites (J. Butler), este artigo centrar-se-á na análise do filme italiano Io Sono L'Amore (2009) de Luca Guadagnino. Embora parecendo retratar uma história aparentemente comum, o filme oferece na verdade uma narrativa profundamente esteticizada dos sentidos - uma "esteticização" da vida quotidiana e uma conceção utópica do corpo. Aplicando ferramentas conceptuais tanto de Estudos dos Sentidos como dos Estudos da Alimentação, acompanharemos a viagem física e emocional de prazer de Emma Recchi e tentaremos compreender como a boa comida pode conduzir ao desejo, aos prazeres da carne e a um conhecimento mais profundo de nós próprios.

Palavras-chave: Estudos dos Sentidos, Estudos de Género, Corpo, Utopia e Cinema

The world is full of magic things, patiently waiting for our senses to grow sharper.

W.B. Yeats

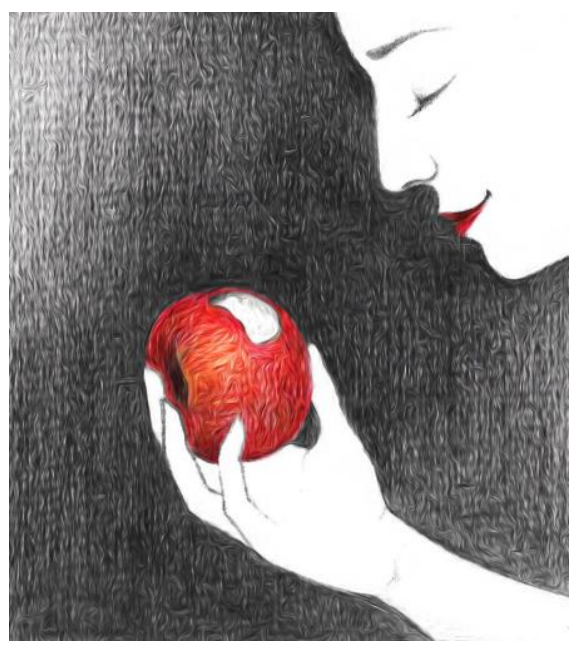

My Love of Knowledge, Mar Lopes de Oliveira $\bigodot^{1}$ 


\section{Introduction}

In a time when minorities and underprivileged groups of our society are under attack, to write about women, bodies, boundaries, and pleasure seems to be mandatory. When "feminism," "activism" and "resistance" are shameful words, our protests should become louder and louder. Being myself a utopian researcher and a human rights activist, I have become more and more aware of the power of dreams, ideals and written words. Therefore, I have chosen for my first paper as a research assistant of the ALIMENTOPIA / Utopian Foodways Project a subject that, more than being an aesthetic exercise, is meant to be a piece of resistance.

Contrary to Kant's notion that all knowledge begins with the senses and ends with reason and that there is nothing higher than reason, I set myself to suggest that, by revising our position regarding the importance of our senses in the production of experience, we will extend our knowledge. This new approach to the senses is fundamental to Gender Studies and Food Studies, especially regarding the correlation between women, food, desire, and resistance.

Would it be accurate to say that in Judeo-Christian tradition the original representation of the senses and food is the myth of a curious woman eating something that she was not supposed to eat and that the punishment for this "sin" was the everlasting damnation of humankind? Was the eating of the apple an act of weakness of character? Was Eve so weak and lacking in self-restraint that her desire overpowered her reason? Or was it an act of conscious defiance? And, why do tradition, religion, and culture seem to equate food, desire and pleasure with decadence? Especially, the decadence of women? These are some questions I aim to address in this paper.

\section{The Senses: An Overview ${ }^{2}$}

Borrowing Steven Connor's words, our relation to our senses has been one of "active and constructive management" (2006: 9). This means we either dangerously surrender to the senses and are inundated by sensuality and our most basic instincts, or we hierarchize, regulate and discipline them. As to the former, the dangers in surrendering to the senses 
have always been perceived as definitive and spiritually damning, hence avoided. For centuries, academics, intellectuals, scientists, even artists, have stood for the dominance of reason over emotion, mind over body. However, the need to discipline and regulate the senses has been imposed on us not only by individuals but also by institutions. It has been enforced by education and embedded in cultural discourse.

In the early Christian worldview and throughout the Middle Ages, the senses were normally regarded as the lower component of the human being; the more humans yielded to their senses the more bestial they would become. For instance, a common medieval conception of the soul perceived it as a city, of which the senses formed the gateways to the deceitful and dangerous world. Following this notion, there was the need for human beings to temper the senses, even mortify them, to attain some kind of atonement, of divinity. The ascetic lifestyles and bodily mortification performed by some religious orders were practical examples of the application of this thesis.

During the Renaissance period, and particularly the Enlightenment and its advocacy of "taste," the prevailing theory was the suppression of the then considered grosser senses and the refinement and education of the higher senses, usually associated with sensibility and reason. In fact, since the Classical era it had been common practice to rank the senses according to their importance, as they were regarded as the means to enhance spiritual insight. This tradition regained its force during the Enlightenment. The scale could vary, but usually predominance was given to vision and hearing. In consonance with the Christian iconography, the eyes were considered the highest organ in upright men and were frequently associated with knowledge (i.e. the all-seeing eye of god), whereas hearing was perceived as the channel for understanding and obedience, through which god himself would speak to his elect. Due to these associations with divinity and control over mundane things, these two senses have always been taken to the forefront in European imagery. Farther down the scale, there were the other three senses in various orders: smell, taste, and touch. Although their position diverges from text to text, the fact is that they were unchangeably considered the lowest of the senses. Associated with sexuality, gluttony, and 
excess, they represented human beings' greatest weakness that is to succumb to their most primitive nature (see Howes 2015).

This perception has become an intrinsic part of our culture, identity, and discourse for centuries. Since the foundation of the so-called Western Civilisation until the end of the $20^{\text {th }}$ Century, we rejected the vital role of the senses in the construction and understanding of social experience.

Differently from animals that seem to merely employ their senses, human beings construct theirs and construct themselves through them. Romain Bragard claims that "social phenomena are sonorous, visual, tactile, gustatory and olfactory phenomena" (apud Howes 2015: viii). In other words, living employs the senses; it is an experience of sharing of the sensible, it is what François Laplantine, a French anthropologist and the author of The Life of the Senses: Introduction to a Modal Anthropology, refers to as partage du sensible [sharing of the sensible] (idem: ix). A colourful way to exemplify this effect is a voyage to an exotic country: we observe new/strange customs, speak and listen to new languages, partake of other peoples' cuisine and empathise or not with their experiences.

As written on the presentation page of The Senses and Society Journal, "[s]ensation is fundamental to our experience of the world. Shaped by culture, gender, and class, the senses mediate between mind and body, idea and object, self and environment". ${ }^{3}$ In fact, the sensorium, which is the entire perceptual apparatus of the human body, is an ever-shifting social and historical construct. It is cultural and political, not simply a matter of cognitive processes or neurological mechanisms located in the individual subject. The emergent and growing research from cultural studies carried out by scholars on the sociality of sensation, i.e. the social understanding of the senses, emphasises the thesis that sensation is not only essential to our experience of reality and the world but vital in understanding ourselves.

Laplantine's view is founded upon the notion of the "multiplicity of the body's modalities of perception" that "all anthropology is an anthropology of the body" (apud Howes 2015: xii). This innovative thesis, which promotes plurality and assimilation, deconstructs completely the unity, totality, and universality of concepts such as the intelligible and the sensible. This is a vital issue not only because it refutes the conceptual 
systems built upon binaries and false universals, but also because it negates the constant need to hierarchize one element over the other that these systems perpetuate. In this case, according to tradition, predominance was almost invariably given to "the intelligible" over "the sensible," mind over body. Following this, Laplantine refuses to acknowledge the dichotomy of cognition over perception. His view of the continuity of sensation and the ultimate indomitability of the life of the senses tries to prove that there is a political and a historical dimension to the sensory experience, which exceeds what individuals can consciously experience (apud Howes 2011: 83). It is thus imperative to combine both cognition and perception.

The senses were already seen as an academic topic of research before Sensory Studies emerged - that is a fact. However, what is new about Sensory Studies is that they aim to beyond what has been done in the fields of Psychology and Neurology, investing in an analysis of the senses that surpasses the consideration of their mere physical functions. Laurence J. Kirmayer explains how the focus of research has changed:

Contemporary cognitive neuroscience understands mind and experience as phenomena that emerge from neural networks at a certain level of complexity and organization. There is increasing recognition that this organization is not confined to the brain but also includes loops through the body and the environment, most crucially, through a social world that is culturally constructed. On this view, 'mind' is located not in the brain but the relationship of brain and body to the world. (apud Howes 2011: 165-166; emphasis added)

The senses are these "loops," the gateways, at once bearers and shapers of culture. As Howes explains, by examining the ways of sensing through which people make sense of the world, "it becomes possible to arrive at a full-bodied, multimodal understanding of the richness and diversity of being alive" (idem: xiv). Diversity, inclusiveness, and subjectivity are key concepts in Sensory Studies since the main objective of this field of research is indeed to open our eyes to the complexity of relations among human beings, between humans and the world and even between humans, the world and the Arts. 


\section{Savouring Desire: Of Taste and the Female Body}

Analysing - perhaps a bit crudely - the general outlook throughout European History and recalling that powerful image in the Judeo-Christian iconography of Eve eating the apple, we understand that nothing has ever been more regulated and disciplined than women. As Judith Butler claims, "Bodies matter" - especially women's bodies (1993: 2150). They are constructed and do not belong to their confined physical boundaries. Bodies cannot be fixed; they indicate a world beyond themselves that can confirm or refute preconceptions created about them. Still very much shaped by the binary frame of mind, women's bodies are perceived as either seductive and damning or maternal and almost asensual. This is exactly what this paper seeks to challenge here. Women's desires, appetites and psyche are much more complex than this castrating view allows us to see.

In a patriarchal society as ours, women have always been perceived as the source of sensuality and all its menaces. Their powers of seduction seem to have no bounds and at some point in History their bodies were even considered channels for men's damnation. Even today, in the $21^{\text {st }}$ century, the female body is still a source of controversy. Although there has been an eager attempt from some companies to change this, the marketing and show business industries keep resorting to (female) body shaming and unrealistic physical ideals as strategies to increase sales. There are even political leaders of the so-called "free world" who expect their female members of staff to "dress like women," meaning that they should wear dresses, skirts, and high heels. On the other hand, women are in some places humiliated and threatened for breastfeeding their children in public spaces. Without mentioning the public and established disbelief, they still face when reporting abuse. ${ }^{4}$ However, the greatest taboo of all is women's desire. Unless it is debated or used for men's benefit, women's sexuality is still a non-topic.

"My anatomy is only part of an infinitely complex organisation, my self", writes Angela Carter in The Sadeian Woman (2006: 4; emphasis added). In this powerful text, Carter denounces and negates, through an appraisal of Marquis de Sade's oeuvre, the deeprooted idea that women have no sex drive whatsoever apart from their instinct to procreate. According to Carter, de Sade was the first male author (man?) to recognise 
women as more than mere reproductive machines. In this critical text, Carter deconstructs iconography, mythology, and pornography to expose "the repression and taboo that governs [women's] experience of flesh" (2006: 11). This issue does not pass unnoticed in Carter's fiction either. Indeed, in her fictional texts, sex and power are intrinsically associated with food and eating. These entities share a profound and ambiguous connection that more often than not suggest a confusion of appetites. As Sarah Sceats in Food, Consumption and the Body in Contemporary Women's Fiction explains, eating can be an erotic activity, where food is the focus of desire and eating is the central act (2000: 25). In literature written by women in general, food and eating seem to be a central and versatile trope to express desire, sexual appetite, and resistance. Food can be the conductor to/of sex, and together they may embody an insatiable eroticism. Moreover, these changes can lead the (female) characters through individual awakening and social resistance, as we will later understand.

Eating is a vital activity, not only because nourishment is indispensable for survival but also because it is inherently connected with social function. As Sceats points out, "what people eat, how and with whom, what they feel about food and why [...] are of crucial significance to an understanding of human society" (2000: 2). The major implications of eating are not biological, but in fact symbolic, and are inseparable from questions of gender, power, and control. The people's or characters' relation to food conveys meanings that result from diverse factors: longings or hunger, deep associations between food and the (female) psyche, specific socio-cultural pressures, especially regarding women's bodies and cultural and artistic inscriptions, just to name a few (idem: 8). When it comes to women, food is inevitably associated with nurturing, sensuality and sexual appetite and it can become "a universal signifier." Borrowing Sceats's words, "food is a currency of love and desire, a medium of expression and communication" (2000: 22), particularly for women. Confined to the private sphere in general and to the kitchen in particular, women have used cooking and eating as a means to convey their feelings. In Babette's Feast by Karen Klixen, for instance, food is a way of declaring connection within a community, goodwill, generosity, and solidarity. In this case, cooking and eating attain collective and cultural 
significance. ${ }^{5}$ A different case is Como Agua para Chocolate [Like Water for Chocolate] by Laura Esquivel, in which the main character, Tita, resorts to cooking to express her desire for her brother-in-law, Pedro. By feeding her family, Tita keeps the passion she and Pedro share alive and awakens the desires the rest of the family have buried. As we can see, the significances of food and eating, like those of sexuality, can not only vary extensively but are also psychologically, socially and politically construed. Alimentary symbols, customs, and behaviours are indicators and results of cultural conditioning (cf. Sceats: 5). Similar to Tita and Pedro's story is the case of Emma and Antonio, the protagonists of Io sono l'Amore, as food works as catalyst for their relationship, the female body becomes the means and desire the driving force to self-discovery.

\section{Mapping Flavours in Io Sono L'Amore (Luca Guadagnino, 2009) ${ }^{6}$}

Fortunately, there are more and more writers and filmmakers becoming aware of the multi-layered complexity of women (and their sexuality) who create denser female characters, thus broadening our palette of objects of study. Such is the case with Io Sono L'Amore (2009), by the male Italian director Luca Guadagnino

According to François Laplantine, cinema is "made up of permanently transforming sensations." More than an object, film is "a way of knowing" that exceeds the written language, which he perceives as being very limited (Howes 2015: vii). Film relies on images rather than ideas, in emotions rather than reason. It is continuous with the world, sensitive to the slightest gradations and movements and affects. It is a means for thinking sensually.

The main character of Io Sono L'Amore is Emma, a Russian immigrant living in Milan, married to a wealthy man who appreciates beautiful objects and uses them as trophies. Her life is empty, filled only with silence: it seems to us a constant performance, not of her volition of course, because she does not do it to deceive but in any case a façade. She has no friends apart from her husband's family; she has nothing of her own, not even her children who had been raised to comply with the ambition their grandfather had defined for them. Even her name was her husband's idea of a beautiful name. Her Russian - original - name has been forgotten and lost to her. When Emma arrived in Milan and married Tancredi, her 
whole identity was erased; her mind and body became a tabula rasa, ready to be moulded by the Recchi family. Only when she involuntarily becomes aware of her daughter's sexuality and secret love affair with another woman does Emma look at herself with a critical eye and realizes the nothingness of her existence. That is when she meets Antonio, her son Eduardo's friend and a gourmet chef.

Emma and Antonio meet during the party preparations for Eduardo's birthday, and Emma is seduced even before she actually sees Antonio. At the mere sight of Antonio's dish and the first taste of it, Emma becomes oblivious to her surroundings and experiences a climatic - orgasmic even - sensation that she had not felt in a very long time. A part of her that has been dormant resurfaces and triggers a transformation for which nobody was prepared, Emma least of all. Unexpectedly, she surrenders to this sensation and strips herself of the Recchis' values through her palate. Indeed, it is not Antonio that saves her from her void existence, but his food. Antonio and his scrumptious food are the catalysts to her liberation and ultimately her self-empowerment. Through a combination of two different appetites, Emma experiences lust, love, and liberty to be herself. Food becomes to Emma the conductor to sex, and both food and sex became a relation of insatiable eroticism that she experiences through Antonio's masterly control of the senses, especially palate and touch.

Throughout the film, emotions such as love, desire, loss, nostalgia and palatable pleasures are intrinsically connected with motion and touch. They are indeed fundamentally perceived and expressed through tactile gestures and are conveyed in the scenes, for instance, when Emma's hand caresses fabrics, books, flowers, the grass or even when Antonio is handling ingredients and undressing Emma. These emotions are successfully transported from the screen to the viewers through a combination of close-ups and vibrant colours. The deepening of touch from surface to depth, from the - at first - shy, hesitant touch of the skin to a total immersion involving the characters, takes the spectators on a voyage through Emma's past, present, and future. At the same time, they also embark on an intimate experience. Our relationship with cinema is one of close connection, rather than one of distant observation, and this relationship is especially powerful in this film. 
"Touch" comes to mean not simply contact, but rather a profound manner of being. Jennifer Barker clearly explains this notion when writing that: "[t]actility is a mode of perception and expression wherein all parts of the body commit themselves to, or are drawn into, a relationship with the world that is at once a mutual and intimate relation of contact. The intimate and close contact between touching and touched [...] are universal structures" (2009: 3).

In Io sono l'Amore the intimate contact of touching is intertwined with the palatable delights of sophisticated food to express Emma's sexual and emotional awakening. This relationship becomes fundamentally erotic. As Emma and Antonio do on screen, so film and viewers come together in a mutual exchange between two bodies who communicate their desire, not only for the other but for themselves in the act of touching. A similar symbiosis happens in the eating scenes. In the famous lunch scene, as Emma deconstructs the dish and eagerly devours the prawns, we witness her own deconstruction: she becomes aware of the pleasures she has been missing since she married Tancredi. The viewers sense this because of the close-up and slow motion techniques used by Guadagnino, as well as all the red - a colour commonly associated with desire - that embellishes the scene (the dish, Emma's dress and lips). Food and desire are two entities so mixed up together that Emma, surrendering to one, inevitably succumbs to the other. Food and Emma's body can, therefore, be considered main characters in the plot.

In Io sono l'amore, food is an extension of one's body; an extension of a mother's love for her son (Emma's relation with her son's Eduardo is also very much shaped by their relation with food) and an extension of a woman's love for her lover. Antonio is the artist whose talents are put to work to fulfil the needs of these raw materials that are Emma's body and the actual ingredients. Antonio sculpts her body as one of his delicious dishes and tastes every piece of it. Through this process, Emma reaches a new physical and emotional stage and relives forgotten sensations, such as, the feeling of belonging that she had not experienced since she arrived in Italy, as well as a new awareness of her own worth.

This transformation reaches its peak during the period in which Emma and Antonio live secluded on his farm and explore the full extensity of the senses. Emma teaches him to 
cook her favourite Russian dish, ouka soup, which she has only shared with her son Eduardo, and which is one of the last few memories of home she still holds onto. Ouka is a sort of an artifact, an object filled with memory and meaning, symbol of her love for her son and her respect for her Russian roots. Here Emma displays a more "conventional" trait, a maternal side, nourishing and nurturing Antonio; and, while cooking ouka and depicting her "exile," she embodies at the same time an alluring authority of a matriarch and an irresistible vulnerability, going from one extreme of the spectrum to the other.

Spaces associated with the production of food like the kitchen, the restaurant, and especially the farm, where food and Nature are combined in a powerful mixture of appetite, love, and lust, become heterotopic spaces of surrender, as well as resistance: surrender to the pleasures of living according to one's desires and to Nature, while resisting to conventions and morally imposed restrictions. Emma is the embodiment of this complex and rich composition and becomes a utopian construal of the female body. What was at the beginning a performed vision of the Recchi family, a mirror-like projection of their worldview, their wealth, their status, becomes a space of resistance: Emma's resistance as an individual (and not a lifeless extension of the family), as well as her means to reclaim her identity, her cravings, her sexuality.

During this idyllic time, Emma and Antonio experience an Edenic life, as if returning to the most primitive way of living. Emma, just like Eve, succumbs to the pleasure of the forbidden, whereas Antonio figuratively cuts her social restraints off when he cuts her perfect red hair. However, just like Eve, Emma has to pay for putting herself and her pleasure above her responsibilities and the hardest punishment is bestowed upon her: the death of her son. Against all predictions and contrary to all viewers' expectations, though, Emma does not surrender to tragedy and does not return to her husband's "forgiving" arms. Instead, she runs away to be with Antonio.

\section{Conclusion}

Guadagnino's film is what we might call an "aestheticization of everyday life" not only because it is a simple story executed with artistry, but also because, as the original 
meaning of the word entails, it presents a "disposition to sense acutely" (cf. Bull et alii 2006: 6).

Contrary to the binary frame of mind still deep-rooted in mainstream worldview, Emma seems complex, even inscrutable at times. She does surrender to the pleasures of the palate and the flesh, but she does it to (re)find herself, to rebel against her meaningless life. It is an act of defiance, not of weakness. Like Eve, at the first bite she is condemned to curiosity, to knowledge, to constant dissatisfaction and to an endless pursuit of desire.

In times when women and minorities see their rights threatened, it is fundamental to resist; even if resistance is the mere acknowledgment of the right to free ourselves from the social and political paradigms society has imposed upon us. It is fundamental to speak up and rise up against discrimination, misogyny, and oppression, and remember the power of words and symbols. Io sono l'Amore is one example of many cinematic and literary references that resort to food to denounce how the repression of the senses is intertwined with the repression of people and ideas. This film is an ode to the senses. It shows how eating is not merely the consumption of alimentary products, but a vehicle to self-discovery and insurgence against personal and social restrictions. The film and the portrayal it offers of Emma are a eulogy to the decay of everyday life, to the emptiness of the constant strife for power, money and social position. It is, indeed, a piece of resistance. 


\section{Notes}

${ }^{1}$ Used with the artist's permission.

2 This analysis is limited to the European context.

${ }^{3}$ Cf. http://www.sensorystudies.org/the-senses-and-society/. Last access: February 22nd 2017.

${ }^{4}$ A shocking example of this problem was a judicial case that made the news in Portugal only last year of a female judge asking a rape victim whether she had tried to close her legs during the assault.

${ }^{5}$ Cf. Sceats's concept of social eating. According to Sceats, eating is not simply a question of group function, but it is linked to the cultural and political relation of individuals or groups to bigger groups and thus to society (2000: 165). There may even be a potential for some sort of radicalisation, through the encouragement of solidarity or subversive activity (idem: 174-175).

${ }^{6}$ Io Sono L'Amore [I am Love] is a film by the Italian director Luca Guadagnino released in 2009, whose screenplay was a result of the collaborative work of Barbara Alberti, Ivan Cotroneo, Walter Fasano and Guadagnino himself. Tilda Swinton was cast as Emma and Edoardo Gabbriellini as Antonio. For more details, please visit the official movie site: http://www.magpictures.com/iamlove/. 


\section{Works Cited}

Barker, Jennifer M. (2009), The Tactile Eye. Touch and the Cinematic Experience, Berkeley and Los Angeles, University of California Press.

Bull, Michael / Paul Gilroy / David Howes / Douglas Kahn (2006), "Introducing Sensory Studies", in The Senses and Society, 1:1, 5-7.

Butler, Judith (1993), Bodies that Matter. On the discursive limits of 'sex', London, Routledge. Carter, Angela (2006), The Sadeian Woman and the Ideology of Pornography, USA, Penguin Books [1979].

Connor, Steven (2006), “The Menagerie of the Senses”, The Senses and Society, 1:1, pp. 9-26.

Howes, David ed. (2015), François Laplantine's The Life of the Senses. Introduction to a Modal Anthropology, London, Bloomsbury [2005].

-- (2011), "Hearing scents, tasting sights: toward a cross- cultural, multimodal theory of aesthetics", in Francesca Bacci and David Melcher (eds), Art and the Senses. Oxford, Oxford University Press.

Sceats, Sarah (2000), Food, Consumption and the Body in Contemporary Women's Fiction, Cambridge, Cambridge University Press.

\section{Filmography}

Guadagnino, Luca (2009), Io Sono L'Amore, Italy.

\section{Webgraphy}

-- <http://www.sensorystudies.org/the-senses-and-society/> (Last access: February 22nd 2017). 
Joana Caetano completed her Master's Degree in Anglo-American Studies at the Faculty of Arts of the University of Porto (FLUP), with a dissertation on Eschatology and Utopian Thinking during the Cromwellian Period. She is the research assistant to ALIMENTOPIA / Utopian Foodways Project, funded by FEDER - Fundo Europeu de Desenvolvimento Regional funds through the COMPETE 2020 - Operational Programme for Competitiveness and Internationalisation (POCI), and by Portuguese funds through FCT - Fundação para a Ciência e a Tecnologia. In the framework of the Project, she has been doing research in the fields of British Literature and Culture, with special focus on Utopian Studies, Food Studies, and Sensory Studies. She has published a few articles in the fields of her interest, presented several papers at national and international conferences and co-edited an issue of Spaces of Utopia: An Electronic Journal (Series II, Number 2 - 2013). 